\title{
An inducible 1-butanol dehydrogenase, a quinohaemoprotein, is involved in the oxidation of butane by 'Pseudomonas butanovora"
}

\author{
Alisa S. Vangnai ${ }^{1}$ and Daniel J. Arp ${ }^{2}$ \\ Author for correspondence: Daniel J. Arp. Tel: +1 541737 4214. Fax: +1 5417373573. \\ e-mail: arpd@bcc.orst.edu
}

Department of Biochemistry and Biophysics, Laboratory for Nitrogen Fixation Research 1 , and Department of Botany and Plant Pathology², Oregon State University, Cordley 2082, Corvallis, 97331-2902 OR, USA

\begin{abstract}
Butane-grown ' Pseudomonas butanovora' expressed two soluble alcohol dehydrogenases (ADHs), an NAD+-dependent secondary ADH and an NAD+independent primary ADH. Two additional NAD ${ }^{+}$-dependent secondary ADHs could be detected when cells were grown on 2-butanol and lactate. The inducible NAD ${ }^{+}$-independent 1-butanol dehydrogenase (BDH) of butane-grown cells was primarily responsible for 1-butanol oxidation in the butane metabolism pathway. BDH was purified to near homogeneity and identified as a quinohaemoprotein, containing, per mol enzyme, $1.0 \mathrm{~mol}$ pyrroloquinoline quinone (PQQ) and $0.25 \mathrm{~mol}$ haem $c$ as prosthetic groups. BDH was synthesized as a monomer of approximately $66 \mathrm{kDa}$. It has a broad substrate range, including primary alcohols, secondary alcohols, aldehydes, $\mathrm{C}_{4}$ diols and aromatic alcohols. It exhibited the lowest $K_{\mathrm{m}}(7 \pm 1 \mu \mathrm{M})$ and highest $k_{\text {cat }} / K_{\mathrm{m}}$ $\left(72 \times 10^{4} \mathrm{M}^{-1} \mathrm{~s}^{-1}\right)$ value towards 1-butanol. BDH exhibited ferricyanidedependent ADH activity. Calcium ions (up to $10 \mathrm{mM}$ ) increased BDH activity substantially. Two BDH internal amino acid sequences showed 73 and $62 \%$ identity and 83 and $66 \%$ similarity, respectively, when compared with an amino acid sequence of ethanol dehydrogenase from Comamonas testosteroni. The presence of the inducible BDH and secondary ADH may indicate that the terminal and subterminal oxidation pathways are involved in butane degradation of butane-grown ' $P$. butanovora'.
\end{abstract}

Keywords: butane metabolism, 1-butanol dehydrogenase, quinohaemoprotein

\section{INTRODUCTION}

'Pseudomonas butanovora' is a Gram-negative, rodshaped bacterium. It was isolated from activated sludge from an oil-refining plant using $n$-butane as the energy source (Takahashi et al., 1980). Based on morphological, physiological and biochemical characteristics, this organism was grouped in the genus Pseudomonas (Takahashi, 1980). However, the sequence of the $16 \mathrm{~S}$ rDNA gene is most similar to that of members of the genus Azoarcus (N. Hamamura, personal communication). This genus is characterized by members that degrade aromatic compounds (Krieger et al., 1999;

Abbreviations: $A D H$, alcohol dehydrogenase; $B D H, 1$-butanol dehydrogenase; DCPIP, 2,6-dichlorophenolindophenol; EDH, ethanol dehydrogenase; NBT, nitro blue tetrazolium; PMS, phenazine methosulfate; PQQ, pyrroloquinoline quinone.
Philipp \& Schink, 1998) under anaerobic conditions and other members that are plant epiphytes with the ability to fix nitrogen (Reinhold-Hurek et al., 1993). 'P. butanovora' can utilize a variety of organic compounds as growth substrates: $\mathrm{C}_{2}-\mathrm{C}_{9} n$-alkanes, the corresponding primary alcohols, carboxylic acids and some polyvalent alcohols, but not alkenes, sugars or $\mathrm{C}_{1}$ compounds (Takahashi, 1980; Takahashi et al., 1980). Butane-grown ' $P$. butanovora' can degrade several chlorinated aliphatic hydrocarbons (Hamamura et al., 1997), which indicates the potential of butane-grown ' $P$. butanovora' in the bioremediation of sites contaminated with solvents.

Except for the Gram-negative bacteria ' $P$. butanovora' and Pseudomonas sp. strain CRL71 (Hou et al., 1983), most butane-oxidizing bacteria are members of the Gram-positive Corynebacterium-Nocardia-Mycobacterium-Rhodococcus complex (Ashraf et al., 
1994). The pathways for metabolism of gaseous $n$ alkanes $\left(\mathrm{C}_{2}-\mathrm{C}_{4}\right)$ by some of these organisms have been investigated by several techniques. In all cases, metabolism is initiated by a monooxygenase (Ashraf et al., 1994; Hamamura et al., 1999; Perry, 1980; Stephens \& Dalton, 1986; Woods \& Murrell, 1989). Terminal oxidation of an alkane leads to the corresponding 1alcohol, while subterminal oxidation produces the 2alcohol. Evidence for either, and in certain organisms for both, terminal and subterminal oxidation has accumulated. For example, the terminal oxidation of butane was inferred by the induction of isocitrate lyase in Mycobacterium vaccae JOB5 grown on butane or butyrate. Furthermore, isocitrate lyase was not induced when cells were grown on butanone, a predicted intermediate in the subterminal oxidation of butane (Phillips \& Perry, 1974). In contrast, subterminal oxidation of propane was suggested by the accumulation of acetone in propane-grown cells (Vestal \& Perry, 1969). Moreover, an inducible 2-propanol dehydrogenase was purified from M. vaccae JOB5 grown on either propane or 2-propanol (Coleman \& Perry, 1985). Pseudomonas fluorescens NRRL-B1244 can utilize propane, 1-propanol and 2-propanol as growth substrates. Two soluble $\mathrm{NAD}^{+}$-linked alcohol dehydrogenases (ADHs) (one primary $\mathrm{ADH}$ and one secondary $\mathrm{ADH}$ ) were detected in propane-grown cells, which suggested that propane is metabolized through both terminal and subterminal oxidation pathways (Ashraf \& Murrell, 1992). The presence of both terminal and subterminal propane oxidation pathways in Rhodococcus rhodochrous PNKb1 was suggested because mutants unable to utilize either 1-propanol or 2-propanol were also unable to use propane as a growth substrate, indicating that both alcohols are intermediates of propane metabolism (Ashraf \& Murrell, 1992). The terminal oxidation of butane by butane-grown Nocardia TB1 was indicated by the accumulation of butyrate in the presence of appropriate inhibitors (Van Ginkel et al., 1987). These results indicate the diversity of butane and propane oxidation pathways, including the diversity of the ADHs involved in alkane metabolism.

The pathway of butane metabolism by butane-grown ' $P$. butanovora' was recently determined to follow the terminal oxidation pathway, that is butane $\rightarrow 1$-butanol $\rightarrow$ butyraldehyde $\rightarrow$ butyrate (Arp, 1999). Each intermediate (1) accumulated in the presence of appropriate inhibitors, (2) supported cell growth, and (3) stimulated $\mathrm{O}_{2}$ consumption of butane-grown cells. Although no production of 2-butanol was detected, 2-butanol was consumed and stimulated $\mathrm{O}_{2}$ consumption by butanegrown ' $P$. butanovora'. Beers (1988) examined the expression of $\mathrm{ADH}$ in butane-grown ' $P$. butanovora'. Three soluble ADHs (one primary $\mathrm{ADH}$ and two secondary $\mathrm{ADHs}$ ) that required $\mathrm{NAD}^{+}$as an electron acceptor were found. A membrane-bound, $\operatorname{NAD}(\mathrm{P})^{+}-$ independent $\mathrm{ADH}$ was also described.

In this study, we focused on the characterization of the $\mathrm{ADH}(\mathrm{s})$ induced in ' $P$. butanovora' in response to growth on butane. Although butane-grown cells can consume 1- and 2-butanol, it was not known if one ADH was oxidizing both substrates. Our goal was to determine the number and specificity of ADHs present in butane-grown ' $P$. butanovora', and to purify and characterize the inducible $\mathrm{ADH}$ primarily involved in the butane metabolism pathway. We report here on the purification and characterization of a quinohaemoprotein, type II ADH induced in butane-grown ' $P$. butanovora'. This report is the first to describe a quinohaemoprotein produced from $n$-alkane-grown bacteria.

\section{METHODS}

Chemicals. All high-purity alcohols and aldehydes (98$99.99 \%$ ) were purchased from Sigma and Aldrich. Other chemicals used were analytical grade.

Bacterial strains and growth conditions. ' $P$. butanovora' (ATCC 43655) cultures were grown in 121 bottles at $30^{\circ} \mathrm{C}$ with vigorous recirculation of a gas mixture $(1501$ consisting of $10 \%, \mathrm{v} / \mathrm{v}$, butane; $5 \%, \mathrm{v} / \mathrm{v}, \mathrm{CO}_{2} ; 85 \%, \mathrm{v} / \mathrm{v}$, air) through the bottle. The growth medium consisted of, per liter, $8.0 \mathrm{~g}$ $\left(\mathrm{NH}_{4}\right)_{2} \mathrm{HPO}_{4}, 1.9 \mathrm{~g} \mathrm{Na}_{2} \mathrm{HPO}_{4} .7 \mathrm{H}_{2} \mathrm{O}, 2.0 \mathrm{~g} \mathrm{K \textrm {K } _ { 2 }} \mathrm{PO}_{4}, 0.5 \mathrm{~g}$ $\mathrm{MgSO}_{4} .7 \mathrm{H}_{2} \mathrm{O}, 0.06 \mathrm{~g} \mathrm{CaCl}_{2} .2 \mathrm{H}_{2} \mathrm{O}, 0.05 \mathrm{~g}$ yeast extract, and $1 \mathrm{ml}$ of the trace element solution described by Wiegant \& de Bont (1980). For growth on 1-butanol, 2-butanol or lactate, an appropriate amount of each growth substrate was added to the medium to make the final concentration $4 \mathrm{mM}$. Butane and $\mathrm{CO}_{2}$ were omitted from the gas mixture. Cells were harvested at mid- to late-exponential growth phase ( 45-48 h). Cells were harvested by centrifugation (JA-14; Beckman J2-21) $\left(15 \mathrm{~min}\right.$ at $\left.11000 \mathrm{~g}, 4^{\circ} \mathrm{C}\right)$, resuspended at a ration of $1: 1(\mathrm{w} / \mathrm{v})$ in $25 \mathrm{mM}$ Tris $/ \mathrm{HCl} \mathrm{pH} 8.0$ and kept at $-80{ }^{\circ} \mathrm{C}$ until used.

Preparation of soluble fraction and purification of 1-butanol dehydrogenase (BDH). All procedures for preparation of the soluble fraction and further purification were performed at $4{ }^{\circ} \mathrm{C}$ unless stated otherwise. Unbroken cell suspensions were passed three times through a French pressure cell at 55$62 \mathrm{MPa}$. Unbroken cells were removed by centrifugation at $11000 \mathrm{~g}$ for $15 \mathrm{~min}$. The cell-free extract was centrifuged at $200000 \mathrm{~g}$ for $1 \mathrm{~h}$ (SW40; Beckman L8-70); the resulting supernatant was the soluble fraction and the sediment was collected as the membrane fraction.

$\mathrm{BDH}$ was purified from the soluble fraction prepared from butane-grown cells (see above) by the following steps. In each step, the active fraction(s) were selected primarily by activity stain of non-denaturing gels and then the 1-butanol-dependent phenazine methosulfate (PMS) reductase activity of each active fraction was quantified spectrophotometrically. All active fractions were pooled and dialysed against $25 \mathrm{mM}$ Tris/ $\mathrm{HCl}$ buffer $\mathrm{pH} 8.0$ at $4{ }^{\circ} \mathrm{C}$ overnight before being applied to the next column. (i) Fractionation with ammonium sulfate. To the soluble fraction, ammonium sulfate (to $30 \%$ saturation) was gradually added. The resulting precipitate was removed by centrifugation at $14000 \mathrm{~g}$ for $30 \mathrm{~min}$. Additional ammonium sulfate was added to the supernatant to reach $70 \%$ saturation. The resulting precipitate was collected by centrifugation and redissolved at a ratio of $1: 2(\mathrm{w} / \mathrm{v})$ in $25 \mathrm{mM}$ Tris/HCl buffer $\mathrm{pH} 8 \cdot 0$. (ii) Q-Sepharose FPLC. The dialysed $30-70 \%$ ammonium sulfate fraction was applied to a Q-Sepharose anion exchange FPLC column (Millipore) $(2 \cdot 2 \times 10 \mathrm{~cm})$ which had been equilibrated with $25 \mathrm{mM}$ Tris/ $\mathrm{HCl}$ buffer $\mathrm{pH} 8 \cdot 0$. The proteins were eluted by a continuous 
gradient of $0-1 \mathrm{M} \mathrm{NaCl}$ in the same buffer. The $\mathrm{ADH}$ of interest, which has a pinkish-red colour, eluted at 200$250 \mathrm{mM} \mathrm{NaCl}$, while a secondary ADH eluted at approximately $600 \mathrm{mM} \mathrm{NaCl}$. (iii) 4-Amino-1-butanol affinity chromatography. The dialysed Q-Sepharose fraction containing a primary ADH was applied to 4-amino-1-butanol substrateanalogue affinity column prepared as previously described (Beers, 1988; Lange \& Vallee, 1976). The proteins were eluted by a step gradient of $0 \cdot 05,0 \cdot 075,0 \cdot 1,0 \cdot 2$ and $1 \mathrm{M} \mathrm{NaCl}$ in $25 \mathrm{mM}$ Tris/ $\mathrm{HCl} \mathrm{pH} 8 \cdot 0$. Most proteins did not bind to the column. The ADH of interest eluted at $0.05 \mathrm{M} \mathrm{NaCl}$.

Enzyme assays. All enzyme assays were performed at $25^{\circ} \mathrm{C}$. $\mathrm{NAD}^{+}$-independent $\mathrm{ADH}$ activity was routinely measured as PMS reductase activity. PMS reductase activity was measured spectrophotometrically by monitoring the reduction of 2,6dichlorophenolindophenol (DCPIP) at $600 \mathrm{~nm}$ in a reaction mixture consisting of $25 \mathrm{mM}$ Tris $/ \mathrm{HCl} \mathrm{pH} 8 \cdot 0,0 \cdot 7 \mathrm{mM}$ PMS, $0 \cdot 1 \mathrm{mM}$ DCPIP, $4 \mathrm{mM} \mathrm{NH}_{4} \mathrm{Cl}, 0.8 \mathrm{mM} \mathrm{KCN}$ and $1 \mathrm{mM} \mathrm{1-}$ butanol in a total volume of $3 \mathrm{ml}$. The enzyme activity of $\mathrm{NAD}^{+}$-dependent $\mathrm{ADH}$ was measured by the increase in $A_{340}$ due to $\mathrm{NADH}$ in a reaction mixture (total volume $3 \mathrm{ml}$ )

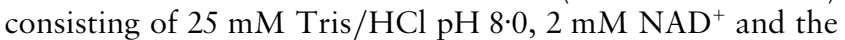
enzyme solution. The endogenous rate of DCPIP or $\mathrm{NAD}^{+}$ reduction obtained without substrate was subtracted from the rate observed with substrate. The reaction mixture $(2 \mathrm{ml})$ for ferricyanide reductase activity assay contained $25 \mathrm{mM}$ Tris/ $\mathrm{HCl} \mathrm{pH} 8 \cdot 0,1 \mathrm{mM}$ potassium ferricyanide, $1 \mathrm{mM}$ 1-butanol and enzyme solution. The enzyme concentration was fixed at $50 \mathrm{nM}$. One unit of enzyme activity was defined as the amount of enzyme catalysing oxidation of $1 \mu \mathrm{mol}$ substrate $\mathrm{min}^{-1}$ under the conditions described. Protein content was estimated by the bicinchonic acid protein assay reagent (Pierce) with bovine serum albumin as a standard (Smith et al., 1986).

Determination of 1-butanol oxidation and product formation by GC. The concentration of substrate (alcohol or aldehyde) utilized and type of products (aldehyde or organic acid) formed were determined by GC (Shimadzu GC-8A column equipped with a flame-ionization detector and $60 \mathrm{~cm}$ long by $0 \cdot 1 \mathrm{~cm}$ i.d. stainless steel column packed with Porapak Q resin). The column temperature was $150^{\circ} \mathrm{C}$ for detection of 1 butanol and butyraldehyde, and $120^{\circ} \mathrm{C}$ for detection of 2 butanol and butanone.

Analytical gel filtration. The molecular mass of native protein was determined by gel filtration $(1.6 \times 30 \mathrm{~cm}$ column $)$ with Sephacryl S-300 (Pharmacia). Elution was performed at a flow

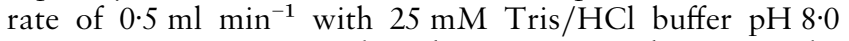
containing $0 \cdot 15 \mathrm{mM} \mathrm{NaCl}$, and was monitored at $A_{280}$. The following molecular mass marker proteins were used for calibration: catalase $\left(M_{\mathrm{r}} 240000\right)$, bovine serum albumin $\left(M_{\mathrm{r}}\right.$ $66000)$, carbonic anhydrase $\left(M_{\mathrm{r}} 30000\right)$ and cytochrome $c\left(M_{\mathrm{r}}\right.$ $13000)$.

Electrophoresis. 10\% SDS-PAGE (Mighty Small SE245; Hoefer Scientific Instruments) (Laemmli, 1970; Woods \& Murrell, 1989) and Coomassie brilliant blue G250 staining were used to analyse the homogeneity of the purified enzyme.

Non-denaturing gel and activity staining. Native protein was applied to non-denaturing gels prepared as above but without SDS. After PAGE, the gel was incubated for 5 min in the dark with a reaction mixture $(50 \mathrm{ml})$ containing $0.01 \mathrm{~g}$ nitro blue tetrazolium (NBT), together with $0.7 \mathrm{mM}$ PMS or $1 \mathrm{mM}$ $\mathrm{NAD}^{+}$alone or in combination. Either 1-butanol or 2-butanol was then added to a final concentration of $1 \mathrm{mM}$ and incubated with gentle rocking for another $5 \mathrm{~min}$ to develop the colour. The reaction was stopped by rinsing the gel with water.
Kinetic measurements. Kinetic parameters were calculated from the initial rates determined with the PMS reductase standard assay described above by varying the concentrations of substrates tested from $2 \mu \mathrm{M}$ to $1 \mathrm{mM}$. The enzyme concentration was fixed at $50 \mathrm{nM}$.

Preparation of antibodies and immunoblotting. Purified BDH $(2 \times 100 \mu \mathrm{g})$ well mixed 1:1 (v/v) with TitreMax adjuvant (Sigma) was injected into two New Zealand rabbits. Two weeks later, a booster injection of another $100 \mu \mathrm{g}$ protein mixed with TitreMax was performed. Another two weeks later, blood was collected, then left at room temperature for $30 \mathrm{~min}$ and overnight at $4{ }^{\circ} \mathrm{C}$. After centrifugation at $1000 \mathrm{~g}$ for $10 \mathrm{~min}$ to remove the erythrocytes, antisera were collected and stored at $-80{ }^{\circ} \mathrm{C}$. For immunoblotting analysis, the proteins in the SDS gel after PAGE were transferred electrophoretically with a semi-dry system (Ausubel et al., 1996) onto a PVDF membrane at $10 \mathrm{~mA}$ overnight. The membrane was washed with $15 \mathrm{ml}$ Tris-buffered-saline (TBS) $(20 \mathrm{mM}$ Tris/ $\mathrm{HCl}, 150 \mathrm{mM} \mathrm{NaCl}, \mathrm{pH} 7 \cdot 5$ ) before blocking with $15 \mathrm{ml} 1 \%$ BSA in TBST (TBS with $0 \cdot 1 \%$ Tween 20) for $1 \mathrm{~h}$. The membrane was then incubated with primary antiserum (at a dilution of 1:5000 in TBST) for $1 \mathrm{~h}$. The membrane was washed twice with TBST before incubation with TBST containing secondary antibody $[1 \mathrm{mg}$ anti-rabbit $\operatorname{IgG}(\mathrm{Fc})$ $\mathrm{ml}^{-1}$; Promega] conjugated with alkaline phosphatase (at a dilution of 1:5000 in TBST) for $30 \mathrm{~min}$. After the membrane had been washed with $20 \mathrm{ml}$ TBST three times, the immunosorbent protein bands were visualized by the addition of $15 \mathrm{ml}$ of Western blue solution (Promega). The colour was developed within 5-20 min. Pre-stained molecular mass marker proteins (Bio-Rad) were included.

Haem staining. A lithium dodecylsulfate-PAGE gel was prepared and pre-run overnight (Delepelaire \& Chua, 1979). Purified BDH was then applied to the gel and run at $5 \mathrm{~mA}$. Haem staining was performed as described by Thomas et al. (1976).

Measurement of haem c content. The amount of haem $c$ in the purified BDH was measured from the reduced minus oxidized difference spectra of the pyridine haemochrome (Paul et al., 1953), using a millimolar absorption coefficient of 26.5 (550-534 nm). The oxidized form of pyridine haemochrome was prepared by adding pyridine to $20 \%(\mathrm{v} / \mathrm{v}), \mathrm{NaOH}$ to a final concentration of $0 \cdot 2 \mathrm{M}$, and potassium ferricyanide to a final concentration of $3 \mathrm{mM}$, to the enzyme solution. To reduce the reaction mixture, $2 \mathrm{mg}$ sodium dithionite was added to the completely oxidized pyridine haemochrome solution. Cytochrome $c$ from horse heart (Boehringer Mannheim) was used to test the protocol and gave a value of $1 \cdot 0$ haem per protein molecule.

Measurement of pyrroloquinoline quinone (PQQ) content. The PQQ content of purified BDH was determined by HPLC analysis as described by Duine et al. (1983).

$\mathrm{N}$-terminal and internal amino acid sequence analysis. To separate the upper and lower bands of the purified $\mathrm{BDH}$, a $13 \times 13 \mathrm{~cm}$ SDS gel was used. Both upper and lower bands were then blotted onto PVDF membrane and the N-terminal amino acid sequences were determined directly. The internal amino acid sequence was obtained by digesting the purified $\mathrm{BDH}$ with endoproteinase Lys-C (Endo Lys-C) in a reaction mixture consisting of $0 \cdot 2 \mathrm{M}$ Tris $\mathrm{pH} 9 \cdot 1,20 \%$ acetonitrile. The enzyme was digested at $37^{\circ} \mathrm{C}$ for $20 \mathrm{~h}$, then DTT was added to a final concentration of $5 \mathrm{mM}$ and incubated at $37^{\circ} \mathrm{C}$ for another $20 \mathrm{~h}$. Peptides in the digest were separated by HPLC using a Vydac C18 column with a Brownlee guard column. The mobile phase A was $0 \cdot 1 \%$ trifluoroacetic acid 
(TFA) and the mobile phase $\mathrm{B}$ was $70 \%$ acetonitrile plus $0 \cdot 1 \%$ TFA. Chromatography was performed with a gradient of from 1 to $65 \%$ phase B in 75 min. Peaks were monitored at $220 \mathrm{~nm}$ and collected for sequence analysis. The prominent fragment was selected for sequencing. The N-terminal and internal amino acid sequencing, including enzyme digestion, were determined by the Biotechnology Laboratory, Institute of Molecular Biology, University of Oregon.

\section{RESULTS}

\section{Multiple ADHs in 'P. butanovora'}

Supernatants from cells grown on different substrates were examined for ADH activities using 1-butanol or 2butanol as substrate. Four distinct activity bands were identified on gels stained for ADH activity when 2butanol was used as a substrate (Fig. 1g). ADH1, which is the enzyme activity band with the fastest mobility, was detected in the presence of PMS when either 1butanol (Fig. 1c) or 2-butanol (Fig. 1f) was added. This activity band was not present with either 1- or 2-butanol when $\mathrm{NAD}^{+}$was used without PMS (Fig. 1b, e) and the presence of $\mathrm{NAD}^{+}$together with PMS did not enhance the band intensities (Fig. 1d, g). Therefore, the activity of ADH1 is $\mathrm{NAD}^{+}$-independent. The intensity of this band varied with the source of the cells. The intensity of ADH1 activity was highest in butane-grown cells and lowest in lactate-grown cells (Fig. 1c, d; lanes 3 and 4, respectively). The activity of $\mathrm{ADH} 1$ was much less when 2-butanol rather than 1-butanol was used as the substrate (Fig. 1f, g). Therefore, this enzyme appears to be a primary $\mathrm{ADH}$ and was designated 1-butanol dehydrogenase $(\mathrm{BDH})$.

Three ADHs (ADH2, -3 and -4 ) were identified as secondary ADHs since they were detected only when 2butanol was used as a substrate (Fig. 1g). None of these secondary $\mathrm{ADH}$ s were detected in 1-butanol-grown cells, while one to two secondary ADHs were detected in 2-butanol-grown, butane-grown and lactate-grown cells

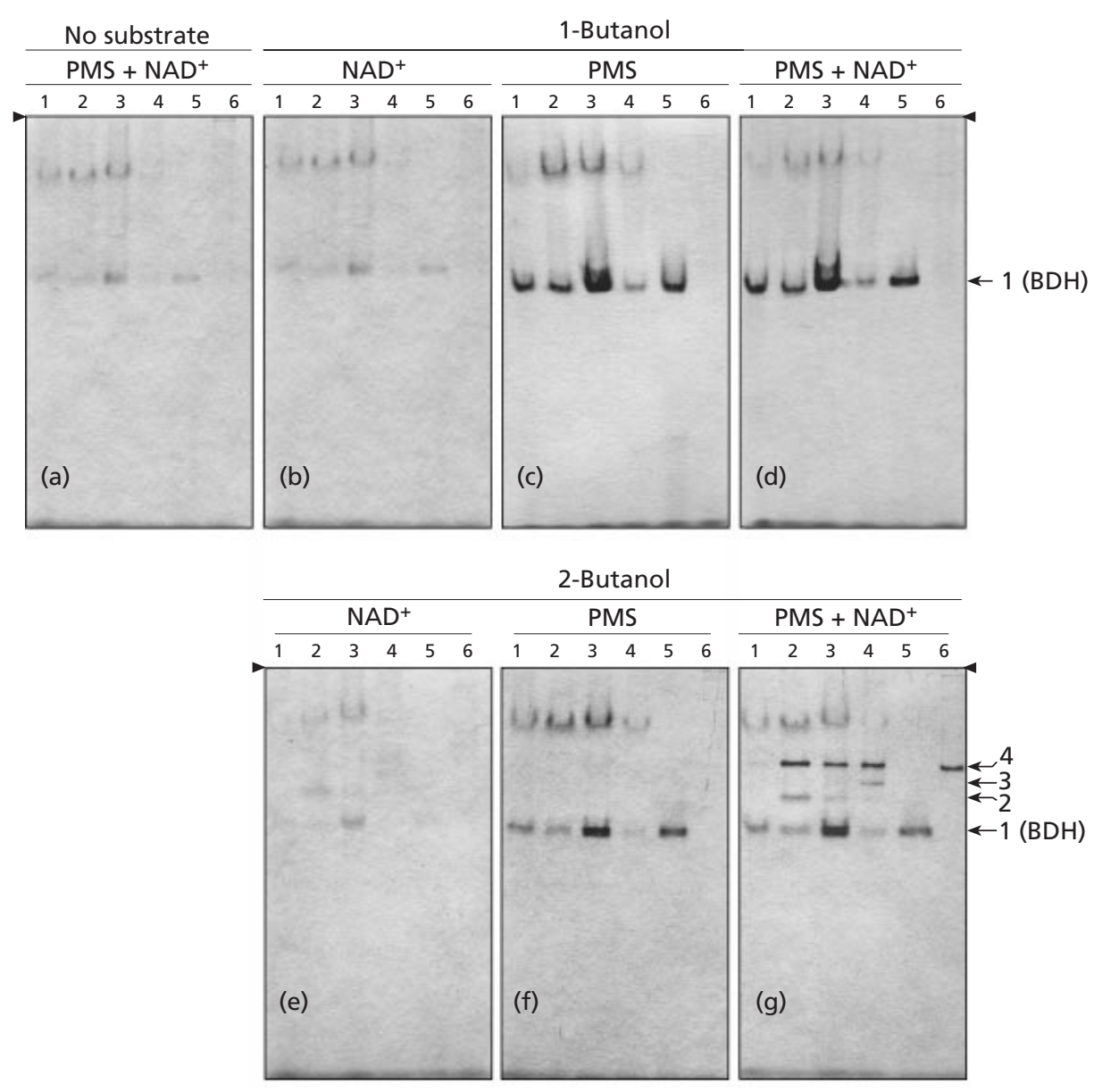

Fig. 1. Non-denaturing gels stained for $A D H$ activity. Native gels after PAGE were stained for 5 min with NBT with NAD alone $(b, e)$, PMS alone $(c, f)$, or PMS and NAD together $(a, d, g)$. Gels were then incubated for an additional 5 min with: no substrate (a), $1 \mathrm{mM}$ 1-butanol (b, c, d), or $1 \mathrm{mM}$ 2-butanol (e, $f, g)$. Lanes 1-4 contain cell-free extracts from cells

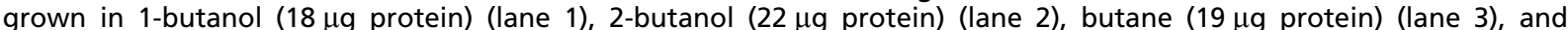
lactate $(22 \mu \mathrm{g}$ protein) (lane 4). Lane 5 contains purified BDH (0.5 $\mathrm{gg}$ protein), and lane 6 contains partially purified secondary ADH ( $20 \mu \mathrm{g}$ protein) from ' $P$. butanovora'. The interface of the stacking gel and the resolving gel are indicated by triangles. Bands corresponding to the four ADHs found in cell-free extracts are indicated. 
(a)
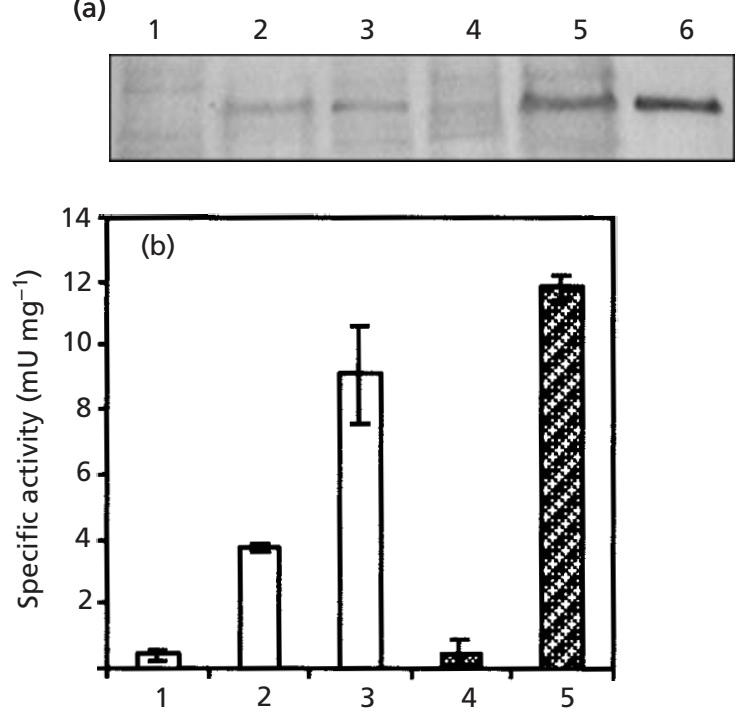

Fig. 2. Induction of BDH during growth of ' $P$. butanovora' on 1-butanol and butane. (a) Western blot analysis of SDS-PAGE of cell-free extracts of ' $P$. butanovora' grown in $5 \mathrm{mM}$ citrate and induced for BDH activity by 1-butanol or butane for 6 and $12 \mathrm{~h}$. The antibodies used were raised against purified BDH from butane-grown ' $P$. butanovora'. Lanes 1-5 contain cell-free extracts from: $12 \mathrm{~h}$ citrate-grown cells $(22 \mu \mathrm{g}$ protein) (lane 1$)$, $6 \mathrm{~h}$ 1-butanol-induced cells $(20 \mu \mathrm{g}$ protein) (lane 2), $12 \mathrm{~h} 1$ butanol-induced cells ( $20 \mu \mathrm{g}$ protein) (lane 3$), 6 \mathrm{~h}$ butaneinduced cells $(18 \mu \mathrm{g}$ protein) (lane 4$)$, and $12 \mathrm{~h}$ butane-induced cells $(23 \mu \mathrm{g}$ protein) (lane 5$)$. Lane 6 contains purified BDH $(2 \mu \mathrm{g}$ protein). (b) 1-butanol-PMS/DCPIP-dependent activity assay of cell-free extracts from: $12 \mathrm{~h}$ citrate-grown cells (1), $6 \mathrm{~h}$ 1butanol-induced cells (2), $12 \mathrm{~h}$ 1-butanol-induced cells (3), $6 \mathrm{~h}$ butane-induced cells (4) and $12 \mathrm{~h}$ butane-induced cells (5).

(Fig. 1g). All three cell extracts contained ADH4, which has the slowest mobility in the non-denaturing gel. 2Butanol-grown and lactate-grown cells contained additional secondary $\mathrm{ADHs}$, designated $\mathrm{ADH} 2$ and $\mathrm{ADH} 3$, respectively. Butane-grown cells exhibited little $\mathrm{ADH} 2$ activity and no AHD3 activity. These secondary ADHs $(\mathrm{ADH} 2,-3$ and -4$)$ all required $\mathrm{NAD}^{+}$for activity and were therefore considered $\mathrm{NAD}^{+}$-dependent. Although no activity was observed with PMS alone, the $\mathrm{NAD}^{+}$-dependent activity also required the presence of PMS (Fig. 1e, f, g). The failure to observe activity with $\mathrm{NAD}^{+}$alone most likely indicated that $\mathrm{NAD}^{+}$cannot act as sole electron acceptor under the conditions tested and indicated a role for PMS in mediating electron transfer from NADH to NBT (Hisada \& Yagi, 1977; Nakamura et al., 1982). The slowly migrating bands that appeared in both the presence and absence of butanol were not attributable to $\mathrm{BDH}$ activity and likely came from nonspecific interactions of the NBT with proteins on the gels (Van Noorden et al., 1985).

\section{BDH is induced during growth of ' $P$. butanovora' on butane}

Growth-substrate-dependent differences in the induction of primary and secondary ADH activities in ' $P$. butanovora' were apparent from the activity-stained non-denaturing gels (Fig. 1c, d). To quantify these differences, BDH activity was determined by spectrophotometric assay in extracts of cells grown on butane, 1-butanol, 2-butanol or lactate. The highest activity was present in cells grown on butane $\left[32.9 \pm 1.7 \mathrm{nmol} \mathrm{min}^{-1}\right.$ $\left.(\mathrm{mg} \text { protein })^{-1}\right]$. The activities of extracts of cells grown on 1-butanol, 2-butanol or lactate were $10 \cdot 6 \pm 0 \cdot 5$, $4 \cdot 4 \pm 0 \cdot 1$ and $1 \cdot 9 \pm 0 \cdot 1 \mathrm{nmol} \mathrm{min}^{-1}(\mathrm{mg} \text { protein })^{-1}$, respectively. The activities determined in solution correlated with the intensities of $\mathrm{BDH}$ activity bands on native gels.

To further confirm the correlation of BDH activity with butane metabolism, the induction of $\mathrm{BDH}$ upon exposure of cells to butane was examined. Cells were grown in citrate $(5 \mathrm{mM})$ because this substrate does not repress the induction of butane metabolism when butane is provided. In contrast, lactate and succinate induce catabolic repression in Pseudomonas (Duetz et al., 1994; Yuste et al., 1998). When cells reached an $\mathrm{OD}_{600}$ of $0.6(2 \mathrm{~d})$, they were divided into three parts. One part remained in the citrate-containing medium, another part received $10 \%$ butane in the gas phase, and the third part was supplemented with 1-butanol (to $4 \mathrm{mM}$ ). Cells were incubated at $30^{\circ} \mathrm{C}$ with shaking. After 6 and $12 \mathrm{~h}$, samples of cells were harvested, washed and broken. Further investigation of the induction of $\mathrm{BDH}$ activity was performed by Western blot analysis. The results from the activity assay were consistent with the increases of cross-reacting band intensities in Western blot analysis. As shown in Fig. 2(a), the cross-reacting band of an inducible $\mathrm{BDH}$ was first seen after cells were incubated with 1-butanol for $6 \mathrm{~h}$. After $12 \mathrm{~h}$, clearly visible crossreacting bands were present in cell-free extracts of 1 butanol-induced and butane-induced cells, but not in citrate-grown cells. The 1-butanol-PMS/DCPIP-dependent activity assay (Fig. 2b) showed 22-fold and 30-fold increases in BDH activity after citrate-grown cells were induced by 1-butanol and butane for $12 \mathrm{~h}$, respectively.

\section{BDH activity is in the soluble fraction}

Our results suggested that an $\mathrm{NAD}^{+}$-independent primary $\mathrm{ADH}$ (i.e. $\mathrm{BDH}$ ) was primarily responsible for 1-butanol oxidation. In contrast, it was previously reported that the enzyme responsible for 1-butanol oxidation in butane-grown ' $P$. butanovora' was a membrane-bound NAD $(\mathrm{P})^{+}$-independent primary ADH (Beers, 1988). Therefore, we carefully examined the membrane fraction for ADH activity. Cells grown on $10 \%$ butane were harvested, broken, then soluble and membrane fractions were separated as described in Methods. Membrane fractions from different cell growth stages (the beginning of exponential phase, $\mathrm{OD}_{600} 0.3-0.5$; mid- to late-exponential phase, $\mathrm{OD}_{600}$ $0.6-0.8$; and stationary phase, $\left.\mathrm{OD}_{600} 1 \cdot 5-1 \cdot 7\right)$ and solubilized in various concentrations $(0 \cdot 05,0 \cdot 1,0 \cdot 5$ and $1 \%$ ) of each of several detergents (Triton X-100, Emulgen and dodecyl- $\beta$-D-maltoside). None of these preparations showed significant BDH activity (less than 
Table 1. Purification steps and specific activity of BDH from butane-grown 'P. butanovora'

\begin{tabular}{|c|c|c|c|c|c|}
\hline Purification step & $\begin{array}{l}\text { Total protein } \\
\qquad(\mathrm{mg})\end{array}$ & $\begin{array}{c}\text { Total activity } \\
(\mathbf{U})^{*}\end{array}$ & $\begin{array}{l}\text { Specific activity } \\
\qquad\left(\mathbf{U ~ m g}^{-1}\right)^{*}\end{array}$ & $\begin{array}{l}\text { Purification } \\
\text { (-fold) }\end{array}$ & $\begin{array}{c}\text { Recovery } \\
(\%)\end{array}$ \\
\hline Crude supernatant & 1921 & 250 & $0 \cdot 13$ & 1 & 100 \\
\hline $\begin{array}{l}\text { 30-70\% Ammonium sulfate } \\
\text { precipitation }\end{array}$ & 840 & 308 & $0 \cdot 37 \pm 0 \cdot 01$ & 3 & 123 \\
\hline $\begin{array}{l}\text { First Q-Sepharose column } \\
\text { fractionation }\end{array}$ & 134 & 208 & $1 \cdot 6 \pm 0 \cdot 06$ & 12 & 83 \\
\hline $\begin{array}{l}\text { First 4-amino-butanol affinity } \\
\text { column fractionation }\end{array}$ & 43 & 143 & $3 \cdot 3 \pm 0 \cdot 02$ & 26 & 57 \\
\hline $\begin{array}{l}\text { Second Q-Sepharose column } \\
\text { fractionation }\end{array}$ & 16 & 55 & $3 \cdot 5 \pm 0 \cdot 04$ & 27 & 22 \\
\hline $\begin{array}{l}\text { Second 4-amino-butanol affinity } \\
\text { column fractionation }\end{array}$ & 7 & 33 & $4 \cdot 8 \pm 0 \cdot 34$ & 37 & 13 \\
\hline
\end{tabular}

* Activity was determined as 1-butanol-dependent PMS/DCPIP reduction. One unit (U) of activity was defined as the amount of enzyme catalysing the reduction of $1 \mu \mathrm{mol}$ DCPIP $\min ^{-1}$ under the specific conditions of the assay described in Methods.

(a)

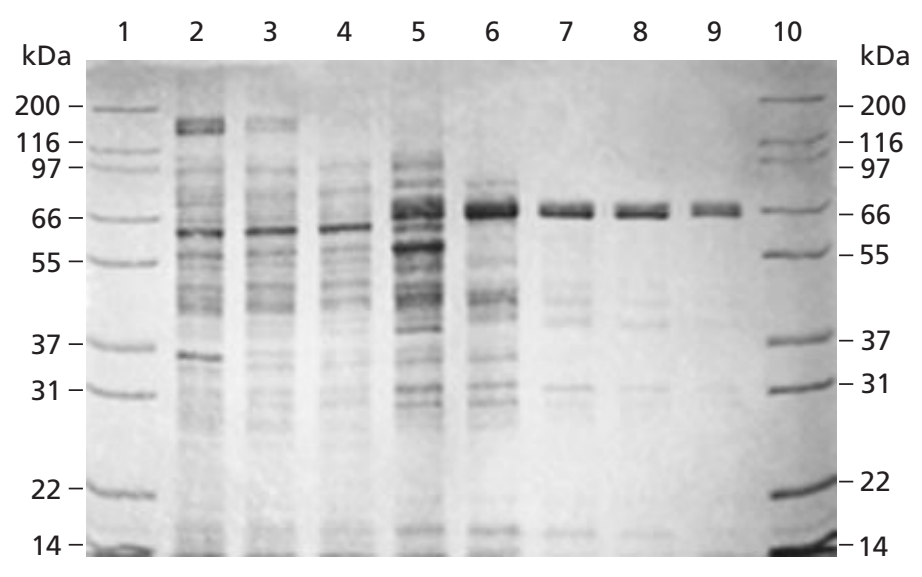

(b)

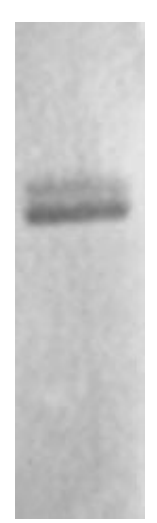

Fig. 3. $10 \%$ SDS-PAGE and Coomassie blue staining of BDH from butane-grown ' $P$. butanovora' after purification steps. All lanes contain approximately $5 \mu \mathrm{g}$ protein. (a) Lanes: 1 and 10, molecular mass markers; 2, cell-free extract; 3, crude supernatant (after membrane fraction had been removed); 4, after 30-70\% ammonium sulfate precipitation; 5, after first Q-Sepharose column fractionation; 6, after first 4-amino-butanol affinity column fractionation; 7, after second QSepharose column fractionation; 8, after second 4-amino-butanol affinity column fractionation; 9, Sephacryl S-300 (for molecular mass verification and subunit determination purposes). (b) The purified BDH was re-run in a large SDS gel to separate two bands (67000 and $65700 \mathrm{Da}$ ), which were then blotted onto PVDF membrane and sequenced.

$2.5 \%$ of the specific activity obtained from soluble fraction) whether $\mathrm{NAD}^{+}$or PMS/DCPIP was used in the activity assay (data not shown). Therefore, the soluble fraction from butane-grown ' $P$. butanovora' was used as an enzyme source for $\mathrm{BDH}$ purification.

\section{Purification and physical properties of BDH}

$\mathrm{BDH}$ activity was the predominant $\mathrm{ADH}$ activity in butane-grown cells. The activity was closely correlated with butane metabolism. Therefore, we focused on this enzyme for additional characterization. BDH from butane-grown ' $P$. butanovora' was purified from the soluble fraction to near homogeneity by a six-step procedure (Table 1). Many contaminating proteins were removed by the first anion exchange (Q-Sepharose) column fractionation, which was followed by a butanol affinity column fractionation. Repeating these two column fractionations was sufficient to purify the BDH to near homogeneity. The 37 -fold increase in specific activity indicated that $\mathrm{BDH}$ accounted for about $2 \cdot 7 \%$ of soluble protein.

A doublet was observed when the purified enzyme was analysed by $10 \%$ SDS-PAGE (Fig. 3a). The purified $\mathrm{BDH}$ was re-run in a large SDS gel (Fig. 3b) to separate these two bands $(67000$ and $65700 \mathrm{Da})$, which were then blotted onto PVDF membrane and sequenced. The N- 
Table 2. Alignment of the $\mathrm{N}$-terminal and internal amino acid sequences of BDH from butane-grown ' $P$. butanovora' and the quinohaemoprotein EDH from C. testosteroni

\begin{tabular}{|c|c|c|c|c|}
\hline Organism & \multicolumn{2}{|c|}{ Amino acid sequence ${ }^{*}$} & \multirow{2}{*}{$\begin{array}{l}\text { Identity } \\
\quad(\%)\end{array}$} & \multirow{2}{*}{$\begin{array}{l}\text { Similarity } \\
(\%)\end{array}$} \\
\hline 'P. butanovora' & $\begin{array}{l}\mathrm{N} \text {-terminal upper band } \\
\mathrm{N} \text {-terminal lower band }\end{array}$ & $\begin{array}{l}\text { AGGEWRT-GYD-A-T } \\
\text { AGGEWRTAGY-DA-T }\end{array}$ & & \\
\hline $\begin{array}{l}\text { 'P. butanovora' } \\
\text { C. testosteroni }\end{array}$ & $\begin{array}{l}\text { Internal sequence } \\
\text { Internal sequence } \\
(427-446)\end{array}$ & 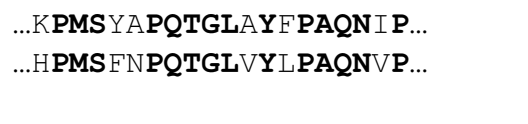 & 73 & 83 \\
\hline $\begin{array}{l}\text { 'P. butanovora' } \\
\text { C. testosteroni }\end{array}$ & $\begin{array}{l}\text { Internal sequence } \\
\text { Internal sequence } \\
(646-670)\end{array}$ & $\begin{array}{l}\ldots K G G G I P N L G Y S T A E T I A H L D Q F V F K . . \\
\ldots \text { RGGNIPNLGYMDASYIENLPNFVFK... }\end{array}$ & 62 & 66 \\
\hline
\end{tabular}

*Bold letters indicate identical residues.

terminal amino acid sequence obtained from each band of $\mathrm{BDH}$ revealed that, in fact, they belonged to the same enzyme (Table 2). This N-terminal amino acid sequence revealed no strong similarity to any $\mathrm{N}$-terminal amino acid sequence in the databases. This result was not surprising since it has been previously reported that there is generally a low similarity in the $\mathrm{N}$-terminal part of this type of protein (Stoorvogel et al., 1996; Zarnt et al., 1997). To obtain internal amino acid sequences from $\mathrm{BDH}$, an endoproteinase Lys-C digestion was performed and two fragments were purified by HPLC and sequenced. Two alignments of the internal amino acid sequences showed high similarities to parts of quinohaemoprotein ethanol dehydrogenase (EDH) from ethanol-grown Comamonas testosteroni, one having an identity of $73 \%$ and a similarity of $83 \%$ to a part of the $\mathrm{EDH}$ amino acid sequence (residues 427-446) and the other one having an identity of $62 \%$ and a similarity of $66 \%$ to a part of the EDH amino acid sequence (residues 646-670) (Table 2).

The secondary ADH observed in butane-grown cells (ADH4) was also partially purified from the soluble fraction by the anion-exchange chromatography step (Fig. 1, lane 6). The partially purified ADH4 did not oxidize 1-butanol (either with $\mathrm{NAD}^{+}$or PMS), but oxidized 2-butanol when $\mathrm{NAD}^{+}$was provided.

The molecular mass of $\mathrm{BDH}$, the primary $\mathrm{ADH}$, was estimated to be $66 \mathrm{kDa}$ by SDS-PAGE (Fig. 3) and $69 \mathrm{kDa}$ by gel permeation chromatography (Sephacryl S-300), which indicates that BDH exists as a monomer. This characteristic is similar to other monomeric quinohaemoproteins with a range of molecular masses of 69-73 kDa (Groen et al., 1986; Hopper et al., 1991; Toyama et al., 1995; Zarnt et al., 1997). Because of the sequence similarity to the quinohaemoprotein $\mathrm{EDH}$, the PQQ content of $\mathrm{BDH}$ was examined. BDH contains an almost 1:1 molar ratio of PQQ [0.99 nmol (nmol protein $)^{-1}$ ], which indicates that PQQ was not lost during the purification. It has been reported that PQQ is non-covalently bound to quinohaemoprotein-type enzymes and can be dissociated by dialysis overnight in

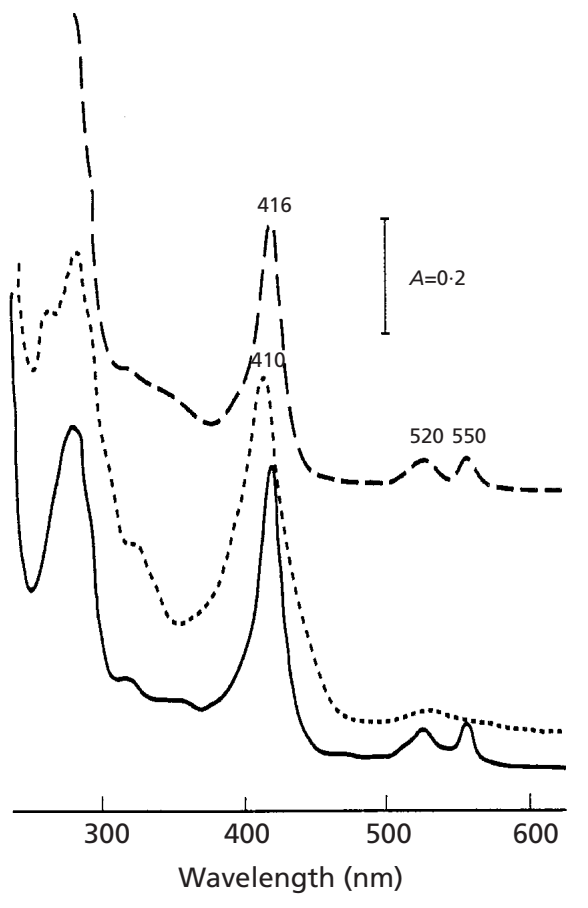

Fig. 4. UV/visible spectra of purified $B D H(10 \mu \mathrm{M})$ from butanegrown ' $P$. butanovora' measured in $25 \mathrm{mM}$ Tris/ $\mathrm{HCl} \mathrm{pH} 8.0$. Purified BDH; ----, BDH oxidized with $200 \mu \mathrm{M}$ potassium ferricyanide; --, BDH re-reduced by the addition of $1 \mathrm{mM} 1$ butanol to the oxidized enzyme.

Tris/ $\mathrm{HCl}$ buffer $\mathrm{pH} 8.0$ containing 2 mM EDTA (Zarnt et al., 1997) or by heat treatment (Toyama et al., 1995).

$\mathrm{BDH}$ exhibits a pinkish-red colour in solution and appears as a red band in non-denaturing gels. A haemstaining band corresponding to a molecular mass of $65 \mathrm{kDa}$ (data not shown) suggested the presence of haem cofactor in this enzyme. BDH as isolated exhibited a typical spectrum of reduced $c$-type cytochrome with absorption peaks at $416 \mathrm{~nm}$ ( $\gamma$ peak), $520 \mathrm{~nm}(\beta$ peak) and $550 \mathrm{~nm}$ ( $\alpha$ peak) (Fig. 4). When BDH was oxidized 
with $200 \mu \mathrm{M}$ potassium ferricyanide, the $\alpha$ and $\beta$ peaks disappeared and the $\gamma$ peak was shifted to $410 \mathrm{~nm}$ (Fig. 4). This spectral change from the reduced form to oxidized form is characteristic of cytochrome $c$.

The BDH absorption spectrum resembles the absorption spectra obtained for other quinohaemoproteins, for example, the absorption spectra of lupanine hydroxylase, with peaks at 416, 522 and $551 \mathrm{~nm}$ (Hopper et al., 1991); of ADH of Pseudomonas putida HK5, with peaks at 418, 523 and $550 \mathrm{~nm}$ (Toyama et al., 1995); of tetrahydrofurfuryl ADH from Ralstonia eutropha, with peaks at 419, 523 and $552 \mathrm{~nm}$ (Zarnt et al., 1997); and of holoenzyme EDH from C. testosteroni (de Jong et al., 1995). When $1 \mathrm{mM}$ 1-butanol was added to the oxidized enzyme, it acted as an electron donor and reduced the $c$ type haem in BDH (Fig. 4). This result indicated the participation of a cytochrome- $c$-type prosthetic group in the catalytic activity of BDH. From the 'reduced minus oxidized' difference spectrum of pyridine haemochrome (at an absorbance of 534 and $550 \mathrm{~nm}$ ), a ratio of $1.0 \mathrm{~mol}$ haem per $3.8 \mathrm{~mol} \mathrm{BDH}$ enzyme was calculated. Typically, quinohaemoproteins contain haem at a $1: 1$ molar ratio (de Jong et al., 1995; Toyama et al., 1995; Zarnt et al., 1997). Although we cannot exclude the possibility, a loss of haem during purification seems unlikely given that $c$-type haems are generally covalently attached to the protein. Perhaps the substoichiometric haem $c$ content reflects an incomplete assembly of haem $c$ into $\mathrm{BDH}$ under the conditions used for growing cells. The presence of two forms of $\mathrm{BDH}$, one with and one without haem $c$, likely explains the presence of two bands on SDS-PAGE gels (Fig. 3a, b).

\section{Catalytic properties of BDH}

In addition to the 1-butanol-dependent PMS/DCPIP activity of $\mathrm{BDH}$, we also examined its ferricyanide reductase activity, which is one of the characteristics of quinohaemoproteins. The ferricyanide reductase activity exhibited by BDH from butane-grown ' $P$. butanovora' was $0.62 \pm 0 \cdot 2 \mu \mathrm{mol} \mathrm{\textrm {min } ^ { - 1 }}$ (mg protein) $^{-1}$ when 1-butanol was used as substrate.

The effect of calcium ions on BDH catalytic activity was determined. The presence of $\mathrm{Ca}^{2+}$ ions facilitated the reconstitution of inactive apoenzyme (PQQ-free, but haem-c-containing) quinohaemoprotein from C. testosteroni and alkaloid-degrading Pseudomonas and increased the $\mathrm{ADH}$ catalytic activity (de Jong et al., 1995; Groen et al., 1986; Zarnt et al., 1997). $\mathrm{Ca}^{2+}$ fulfils a structural role upon reconstitution of apoenzyme with PQQ, facilitating the binding of PQQ to an apoenzyme and activating the bound cofactor (Groen et al., 1986; Zarnt et al., 1997). The activity of BDH from butanegrown ' $P$. butanovora' was significantly increased when $\mathrm{Ca}^{2+}$ was added into the reaction mixture. BDH activity with 1-butanol was increased from $3 \cdot 4 \pm 0 \cdot 2 \mu \mathrm{mol} \mathrm{min}-1$ (mg protein) ${ }^{-1}$ (without $\mathrm{Ca}^{2+}$ ) to $4 \cdot 2 \pm 0 \cdot 01 \mu \mathrm{mol} \mathrm{min}{ }^{-1}$ $(\mathrm{mg} \text { protein })^{-1}$ with $5 \mathrm{mM} \mathrm{CaCl}{ }_{2}$ and $4 \cdot 6 \pm 0 \cdot 2 \mu \mathrm{mol}$ min $^{-1}$ (mg protein) ${ }^{-1}$ with $10 \mathrm{mM} \mathrm{CaCl}_{2}$. The maximal and saturated activity was reached at a $\mathrm{Ca}^{2+}$ concentration of $10 \mathrm{mM}$. $\mathrm{Ca}^{2+}$ was recently reported to have an important role in the catalytic mechanism of quinoprotein-type methanol dehydrogenase (Zheng \& Bruice, 1997). The possible roles of $\mathrm{Ca}^{2+}$ complexed with PQQ in methanol oxidation include: (i) modest reduction of the $\mathrm{p} K_{\mathrm{a}}$ of the substrate and facilitating the association of substrate to active site, (ii) polarizing the oxygen at the C-5 position of PQQ, and (iii) placing the reaction components in the right positions to react, therefore contributing to the formation of enzymesubstrate complex (Zheng \& Bruice, 1997).

BDH activity was increased approximately threefold when ammonium ions (as $4 \mathrm{mM} \mathrm{NH}_{4} \mathrm{Cl}$ ) were present. A similar result was obtained in tetrahydrofurfuryl ADH from R. eutropha where the activity was increased $2 \cdot 5$-fold in the presence of ammonium sulfate (Zarnt et al., 1997).

The optimum $\mathrm{pH}$ for PMS/DCPIP-dependent $\mathrm{BDH}$ activity was 8.0 . The temperature optimum was $60^{\circ} \mathrm{C}$, at which the specific activity was increased $9 \cdot 6$-fold relative to that at $25^{\circ} \mathrm{C}$. The temperature range of maximum stability of the enzyme was $25-32^{\circ} \mathrm{C}$, within which the loss of $\mathrm{BDH}$ activity was insignificant after a $30 \mathrm{~min}$ incubation. In contrast, $\mathrm{BDH}$ activity was decreased $77 \%$ when incubated at $60{ }^{\circ} \mathrm{C}$ for the same period of time. $\mathrm{BDH}$ activity was stable for more than 6 months when stored in $25 \mathrm{mM}$ Tris $/ \mathrm{HCl} \mathrm{pH} 8.0$ at $-80{ }^{\circ} \mathrm{C}$.

$\mathrm{BDH}$ exhibited broad substrate specificity towards various primary alcohols, secondary alcohols, diols, aldehydes and aromatic alcohols (Table 3). Nonetheless, the highest activity was observed with 1-butanol, the butane oxidation product in the terminal oxidation pathway. Therefore, the activities obtained on other substrates were compared to the maximal activity obtained on 1-butanol. Besides 1-butanol, 1-propanol showed a relatively high activity $(66 \%)$ among the primary alcohols tested. The relative activities among primary alcohols decreased with longer-chain alcohols. Little activity $(1-2 \%)$ was detected with methanol, which is consistent with the observation that ' $P$. butanovora' cannot grow with either methane or methanol as a substrate (Takahashi, 1980). Among the secondary alcohols tested, BDH exhibited a marked preference towards 2-pentanol and the activity gradually decreased with longer-chain secondary alcohols. DCPIP was slowly reduced by BDH when 2-propanol or 2butanol was added. In activity-stained native gels, $\mathrm{BDH}$ activity bands were also detected when 2-butanol was added (Fig. 1f, g). However, when 2-butanol consumption was determined directly by GC, no 2-butanol consumption was observed. Furthermore, no butanone formation was detected within the $60 \mathrm{~min}$ assay (data not shown). The low level of DCPIP reduction activity obtained upon addition of either 2-propanol or 2butanol was probably due to the presence of contaminants that supported activity. $\mathrm{BDH}$ was active towards $\mathrm{C}_{4}$ diols when one of the hydroxyl groups was 
Table 3. Substrate specificity of purified BDH from butane-grown ' $P$. butanovora'

Enzyme activity was determined by PMS/DCPIP reduction as described in Methods. Activities are means of at least three replicates. Data are expressed relative to a value of $100 \%$ for BDH activity with 1 -butanol $\left[4 \cdot 8 \pm 0.34 \mu \mathrm{mol} \mathrm{min}^{-1}(\mathrm{mg}\right.$ protein $)^{-1}$.

\begin{tabular}{|lr|lc|}
\hline Substrate & $\begin{array}{c}\text { Relative } \\
\text { activity }(\%)\end{array}$ & \multicolumn{1}{|c|}{ Substrate } & $\begin{array}{c}\text { Relative } \\
\text { activity }(\%)\end{array}$ \\
\hline Primary alcohols & & Diols & \\
Methanol & 2 & 1,2-Propanediol & 4 \\
Ethanol & 34 & 1,3-Propanediol & 5 \\
1-Propanol & 66 & 1,2-Butanediol & 30 \\
1-Butanol & 100 & 1,3-Butanediol & 33 \\
1-Pentanol & 45 & 1,4-Butanediol & 24 \\
1-Hexanol & 29 & 2,3-Butanediol & 2 \\
1-Heptanol & 31 & 1,4-Pentanediol & 1 \\
1-Octanol & 19 & 2,4-Pentanediol & 2 \\
1-Nonanol & 9 & & \\
Secondary alcohols & & Aromatic alcohols & \\
2-Propanol & 5 & Benzyl alcohol & 11 \\
2-Butanol & 9 & Phenol & 13 \\
2-Pentanol & 68 & Aldehydes & \\
2-Hexanol & 56 & Acetaldehyde & 54 \\
2-Heptanol & 49 & Propionaldehyde & 61 \\
2-Octanol & 42 & Butyraldehyde & 78 \\
2-Nonanol & 35 & & \\
\hline
\end{tabular}

at the $\alpha$-position. Benzyl alcohol and phenol were chosen as the representative aromatic alcohols and were slowly oxidized by $\mathrm{BDH}$. $\mathrm{BDH}$ readily oxidized the three aldehydes we tested, with butyraldehyde showing the highest activity. In fact, only 1-butanol was oxidized more rapidly than butyraldehyde.

The kinetic parameters of BDH with 1-butanol and butyraldehyde were determined. At higher concentrations of 1-butanol $(>10 \mathrm{mM})$, the enzyme activity was decreased. BDH exhibited greater affinity towards 1-butanol $\left(K_{\mathrm{m}} 7 \pm 1 \mu \mathrm{M}\right)$ than towards butyraldehyde $\left(K_{\mathrm{m}} 535 \pm 13 \mu \mathrm{M}\right)$. The term $k_{\text {cat }} / K_{\mathrm{m}}$ is used to compare the efficiency of catalysis of $\mathrm{BDH}$ towards different substrates. 1-Butanol was clearly the preferred substrate with a $k_{\text {cat }} / K_{\mathrm{m}}$ of $72 \times 10^{4} \mathrm{M}^{-1} \mathrm{~s}^{-1}$, which is 51 -fold higher than that of butyraldehyde. The product of 1butanol oxidation was butyraldehyde, as determined by GC. A time course experiment confirmed that $\mathrm{BDH}$ prefers 1-butanol to butyraldehyde. 1-Butanol (1 mM) and butyraldehyde $(1 \mathrm{mM})$ were added together as substrates for $\mathrm{BDH}$ in a reaction mixture containing PMS/DCPIP in $25 \mathrm{mM}$ Tris/ $\mathrm{HCl} \mathrm{pH} \mathrm{8.0.} \mathrm{The} \mathrm{oxidation}$ of 1-butanol and butyraldehyde and the formation of their products were determined by GC (Methods). Only 1-butanol was oxidized during the first $60 \mathrm{~min}$, which corresponded with an increase in butyraldehyde. After 1-butanol was completely oxidized, the oxidation of butyraldehyde was initiated and yielded butyric acid. This result is consistent with the 76-fold higher affinity of $\mathrm{BDH}$ towards 1-butanol than towards butyraldehyde.

\section{DISCUSSION}

In this work, four ADHs were detected in ' $P$. butanovora' grown on different growth substrates. The level of expression of each ADH depended on the carbon source used in the medium. ' $P$. butanovora' grown on butane expressed two soluble ADHs, an $\mathrm{NAD}^{+}$-independent primary $\mathrm{ADH}$ and an $\mathrm{NAD}^{+}$-dependent secondary ADH. The $\mathrm{NAD}^{+}$-independent primary ADH has high affinity and activity towards 1-butanol and was expressed at a high level in cells grown on butane or 1butanol. Therefore, this enzyme (BDH) was considered to be of primary importance in the oxidation of 1butanol produced from the terminal oxidation of butane. However, our results contradict a report in which a membrane-bound, $\mathrm{NAD}(\mathrm{P})^{+}$-independent $\mathrm{ADH}$ with an unusually high activity towards methanol ( $>60 \%$ relative to 1 -butanol) was reported to be responsible for the oxidation of butanol in butane-grown 'P. butanovora' (Beers, 1988). In our experiments, no 1butanol oxidation activity could be detected in the membrane fraction.

We purified this soluble, $\mathrm{NAD}^{+}$-independent primary ADH from butane-grown ' $P$. butanovora' and showed it to be a quinohaemoprotein. As pointed out by Toyama et al. (1995), there have been no reports of PQQcontaining ADHs associated with alkane oxidation by bacteria. This work is the first report of a quinohaemoprotein induced from alkane-grown bacteria. Interestingly, this inducible $\mathrm{BDH}$ from butane-grown ' $P$. butanovora' was found to be different from ADHs induced in other alkane-grown Pseudomonas or other short-, medium- or long-chain-alkane-oxidizing bacteria. ADHs induced in propane-grown R. rhodochrous PNKb1, M. vaccae JOB5 and P. fluorescens NRRL B1244 were purified and characterized as $\mathrm{NAD}^{+}$-dependent secondary ADH(s) (Ashraf \& Murrell, 1990, 1992; Coleman \& Perry, 1985). Heptane- and octanegrown Pseudomonas aeruginosa strain 473 contain soluble $\mathrm{NAD}(\mathrm{P})^{+}$-dependent $\mathrm{ADH}$ and at least two $\mathrm{NAD}(\mathrm{P})^{+}$-independent quinoprotein (without haem c) primary ADHs (Van Der Linden \& Huybregtse, 1969).

In addition to methanol dehydrogenase, other quinoprotein $\mathrm{ADHs}$ found in oxidative nonmethylotrophic bacteria have been classified into three groups (types I-III) according to their molecular properties, catalytic properties and localization (Matsushita et al., 1994). The molecular structure of type I ADH resembles that of methanol dehydrogenase, but it has very low affinity for methanol. Type II ADH is a soluble quinohaemoprotein. To date, type II ADHs have been purified from five bacteria: as the apoenzyme, lacking PQQ, from alkaloid-degrading Pseudomonas (Hopper et al., 1991) and C. testosteroni (de Jong et al., 1995; Groen et al., 
1986); and as the active holoenzyme from P. putida HK5 (Toyama et al., 1995), Rhodopseudomonas acidophila M402 (Yamanaka \& Tsuyuki, 1983) and R. eutropha (Zarnt et al., 1997). Type III ADH is a membrane-bound $\mathrm{ADH}$ found in the cytoplasmic membrane of acetic acid bacteria.

The characterization of purified BDH from butanegrown ' $P$. butanovora' indicates that this enzyme is a type II NAD ${ }^{+}$-independent $\mathrm{ADH}$ or quinohaemoprotein (Goodwin \& Anthony, 1998). This is also the first report of a type II NAD ${ }^{+}$-independent $\mathrm{ADH}$ synthesized by an Azoarcus-like bacterium. PQQ, a prosthetic group in quinohaemoprotein, is expected to participate directly in the oxidation of alcohols and aldehydes (Groen et al., 1986). Apo-EDH, lacking PQQ but containing haem $c$, has no activity with alcohol or aldehyde substrates. The presence of haem $c$ as a functional prosthetic group in $\mathrm{BDH}$ was indicated by the following results. (i) A red band, which also stained for ADH activity, was observed in non-denaturing gels. (ii) Protein corresponding to a molecular mass of $65 \mathrm{kDa}$ in lithium dodecylsulfatePAGE also stained positive for haem. (iii) The absorption spectrum of purified $\mathrm{BDH}$, with peaks at 416 , 520 and $550 \mathrm{~nm}$, was a typical reduced cytochrome $c$ spectrum that changed to an oxidized spectrum upon addition of ferricyanide, and back to a reduced spectrum upon addition of 1-butanol. (iv) A ferricyanide reductase activity was exhibited by $\mathrm{BDH}$; quinoproteins, lacking haem $c$, such as methanol dehydrogenase, EDH from $P$. aeruginosa and $P$. putida, and soluble glucose dehydrogenase from Escherichia coli, do not react with ferricyanide, suggesting the oxidation of the enzyme by ferricyanide occurs at the haem $c$ site (Dokter et al., 1986; Geerlof et al., 1994; Groen et al., 1984). For a cell extract from 1-butanol-grown $P$. putida HK5, the ratio of 1-butanol-dependent PMS/DCPIP-reductase activity to ferricyanide-reductase activity was $2: 1$ (Toyama et al., 1995). BDH from butane-grown ' $P$. butanovora' as isolated expressed, with 1-butanol present, a specific activity ratio of PMS/DCPIP reductase activity to ferricyanide reductase activity of $7 \cdot 8$. This specific activity ratio is consistent with the fact that only one quarter of the $\mathrm{BDH}$ as isolated contained haem $c$.

The physical properties of $\mathrm{BDH}$ presented here, including high internal sequence similarity with $C$. testosteroni $\mathrm{EDH}$, indicates that $\mathrm{BDH}$ belongs to the type II quinohaemoprotein group. However, the affinity of $\mathrm{BDH}$ for 1-butanol is much higher than that of $C$. testosteroni $\mathrm{EDH}$ for ethanol or of $R$. eutropha tetrahydrofurfuryl ADH for $n$-pentanol (Geerlof et al., 1994; Zarnt et al., 1997). The $K_{\mathrm{m}}$ of $\mathrm{BDH}$ towards 1-butanol $(7 \pm 1 \mu \mathrm{M})$ is the lowest $K_{\mathrm{m}}$ reported among other quinohaemoprotein ADHs obtained from ethanolgrown C. testosteroni $\left(K_{\mathrm{m}} 2230 \pm 64 \mu \mathrm{M}\right.$ towards ethanol; Geerlof et al., 1994) or 1-butanol grown P. putida HK5 ( $K_{\mathrm{m}} 105 \mu \mathrm{M}$ towards 1-butanol; Toyama et al., 1995). Coupled with much lower affinity for butyraldehyde $\left(K_{\mathrm{m}} 535 \pm 13 \mu \mathrm{M}\right)$, 1-butanol is clearly preferred over butyraldehyde by BDH. In contrast, $C$. testosteroni $\mathrm{EDH}$ has a higher affinity for the aldehyde
( $K_{\mathrm{m}}$ for acetaldehyde $669 \pm 22 \mu \mathrm{M}$ ), such that acetic acid is produced even in the presence of ethanol.

It was recently demonstrated that butane metabolism by ' $P$. butanovora' was mainly via a terminal oxidation pathway (Arp, 1999). Up to $90 \%$ of the butane consumed was accounted for as 1-butanol. The results of this work are consistent with terminal oxidation. The predominant $\mathrm{ADH}$ activity in butane-grown cells is much more efficient towards 1-butanol than 2-butanol. Furthermore, the enzyme is expressed at the highest level observed in butane-grown cells. However, butanegrown cells also expressed a low level of 2-butanoldependent ADH activity that was not present in 1butanol-grown cells. This result may reflect a low level of subterminal butane oxidation involved in butane metabolism in 'P. butanovora'. Studies of the genes encoding each of these enzymes, including expression experiments and gene disruptions, will be pursued to further characterize the role of each $\mathrm{ADH}$ in butane metabolism.

\section{ACKNOWLEDGEMENTS}

This work was supported by NIH grant GM56128 to D. J.A. and the Oregon Agricultural Experiment Station.

\section{REFERENCES}

Arp, D. J. (1999). Butane metabolism by butane-grown 'Pseudomonas butanovora' Microbiology 145, 1173-1180.

Ashraf, W. \& Murrell, J. C. (1990). Purification and characterization of a $\mathrm{NAD}^{+}$-dependent secondary alcohol dehydrogenase from propane-grown Rhodococcus rhodochrous PNKb1. Arch Microbiol 153, 163-168.

Ashraf, W. \& Murrell, J. C. (1992). Genetic, biochemical and immunological evidence for the involvement of two alcohol dehydrogenases in the metabolism of propane by Rhodococcus rhodochrous PNKb1. Arch Microbiol 157, 488-492.

Ashraf, W., Mihdhir, A. \& Murrell, J. C. (1994). Bacterial oxidation of propane. FEMS Microbiol Lett 122, 1-6.

Ausubel, F. M., Brent, R., Kingston, R. E., Moore, D. D., Seidman, J. G., Smith, J. A. \& Struhl, K. (1996). Current Protocols in Molecular Biology. New York: Wiley.

Beers, P. J. (1988). The diversity of alcohol dehydrogenases in Pseudomonas butanovora and their role in alkane metabolism. MSc thesis, University of Warwick.

Coleman, J. P. \& Perry, J. J. (1985). Purification and characterization of the secondary alcohol dehydrogenase from propaneutilizing Mycobacterium vaccae strain JOB5. J Gen Microbiol 131, 2901-2907.

Delepelaire, P. \& Chua, N. (1979). Lithium dodecyl sulfate/ polyacrylamide gel electrophoresis of thylakoid membranes at $4{ }^{\circ} \mathrm{C}$ : characterization of two additional chlorophyll $a$-protein complexes. Proc Natl Acad Sci US A 76, 111-115.

Dokter, P., Frank, J. \& Duine, J. A. (1986). Purification and characterization of quinoprotein glucose dehydrogenase from Acinetobacter calcoaceticus L. M. D. 79.41. Biochem J 239, 163-167.

Duetz, W., Marques, S., de Jong, C., Ramos, J. L. \& van Andel, J. G. (1994). Inducibility of the TOL catabolic pathway in Pseudomonas putida ( $\mathrm{pWWO}$ ) growing on succinate in continuous 
culture: evidence for catabolic repression control. J Bacteriol 176, 2354-2361.

Duine, J. A., Frank, J. \& Jongejan, J. A. (1983). Detection and determination of pyrroloquinoline quinone, the coenzyme of quinoproteins. Anal Biochem 133, 239-243.

Geerlof, A., van Tol, J. B. A., Jongejan, J. A. \& Duine, J. A. (1994). Enantioselective conversions of the racemic C3-alcohol synthons, glycidol and solketal, by quinohaemoprotein alcohol dehydrogenases and bacteria containing such enzymes. Biosci Biotechnol Biochem 58, 1038-1046.

Goodwin, P. \& Anthony, C. (1998). The biochemistry, physiology and genetics of PQQ and PQQ-containing enzymes. Adv Microb Physiol 40, 1-80.

Groen, B. W., Frank, J. \& Duine, J. A. (1984). Quinoprotein alcohol dehydrogenase from ethanol-grown Pseudomonas aeruginosa. Biochem J 223, 921-924.

Groen, B. W., Van Kleef, M. A. G. \& Duine, J. A. (1986). Quinohaemoprotein alcohol dehydrogenase apoenzyme from Pseudomonas testosteroni. Biochem J 234, 611-615.

Hamamura, N., Page, C., Long, T., Semprini, L. \& Arp, D. J. (1997). Chloroform cometabolism by butane-grown CF8, Pseudomonas butanovora, and Mycobacterium vaccae JOB5 and methanegrown Methylosinus trichosporium OB3b. Appl Environ Microbiol 63, 3607-3613.

Hamamura, N., Storfa, R. T., Semprini, L. \& Arp, D. J. (1999). Diversity in butane monooxygenases among butane-grown bacteria. Appl Environ Microbiol 65, 4586-4593.

Hisada, R. \& Yagi, T. (1977). 1-Methoxy-5-methylphenazinium methyl sulfate. A photochemically stable electron mediator between NADH and various electron acceptors. J Biochem $\mathbf{8 2}$, 1469-1473.

Hopper, D. J., Rogozinski, J. \& Toczko, M. (1991). Lupanine hydroxylase, a quinocytochrome $c$ from an alkaloid-degrading Pseudomonas sp. Biochem J 279, 105-109.

Hou, C. T., Patel, R., Laskin, A. I., Barnabe, N. \& Barist, I. (1983). Production of methyl ketones from secondary alcohols by cell suspensions of $\mathrm{C}_{2}$ to $\mathrm{C}_{4} n$-alkane-grown bacteria. Appl Environ Microbiol 46, 178-184.

de Jong, G. A. H., Geerlof, A., Stoorvogel, J., Jongejan, J. A., De Vries, S. \& Duine, J.A. (1995). Quinohaemoprotein ethanol dehydrogenase from Comamonas testosteroni: purification, characterization and reconstitution of the apoenzyme with pyrroloquinoline quinone analogues. Eur J Biochem 230, 899-905.

Krieger, C. J., Beller, H. R., Reinhard, M. \& Spormann, A. M. (1999). Initial reactions in anaerobic oxidation of $m$-xylene by the denitrifying bacterium Azoarcus sp. strain T. J Bacteriol 181, 6403-6410.

Laemmli, U. K. (1970). Cleavage of structural proteins during the assembly of the head of bacteriophage T4. Nature 227, 680-685.

Lange, L. G. \& Vallee, B. L. (1976). Double-ternary complex affinity chromatography: preparation of alcohol dehydrogenases. Biochemistry 15, 4681-4686.

Matsushita, K., Toyama, H. \& Adashi, O. (1994). Respiratory chains and bioenergetics of acetic acid bacteria. Adv Microb Physiol 36, 247-301.

Nakamura, S., Arimura, K., Ogawa, K. \& Yagi, T. (1982). Use of 1methoxy-5 methylphenazinium methyl sulfate (1-methoxyPMS) in the assay of some enzymes of diagnostic importance. Clin Chim Acta 101, 321-326.

Paul, K. G., Theorell, H. \& Akeson, A. (1953). The molar light absorption of pyridine ferroprotoporphyrin (pyridine haemochromogen). Acta Chem Scand 7, 1284-1287.
Perry, J. J. (1980). Propane utilization by microorganisms. Adv Appl Microbiol 26, 89-115.

Philipp, B. \& Schink, B. (1998). Evidence of two oxidative reaction steps initiating anaerobic degradation of resorcinol (1,3dihydroxybenzene) by the denitrifying bacterium Azoarcus anaerobinus. J Bacteriol 180, 3644-3649.

Phillips, W. E. \& Perry, J. J. (1974). Metabolism of $n$-butane and 2butanone by Mycobacterium vaccae. J Bacteriol 120, 987-989.

Reinhold-Hurek, B., Hurek, T., Gillis, M., Hoste, B., Vancanneyt, M., Kersters, K. \& De Ley, J. (1993). Azoarcus gen. nov., nitrogenfixing proteobacteria associated with roots of Kallar grass (Leptochloa fusca (L.) Kunth), and description of two species, Azoarcus indigens and Azoarcus communis sp. nov. Int J Syst Bacteriol 43, 574-584.

Smith, P. K., Krohn, R. I., Hermanson, G. T. \& 7 other authors (1986). Measurement of protein using bicinchonic acid. Anal Biochem 150, 76-85.

Stephens, G. M. \& Dalton, H. (1986). The role of the terminal and subterminal oxidation pathways in propane metabolism by bacteria. J Gen Microbiol 132, 2453-2462.

Stoorvogel, J., Kraayveld, D. E., Vansluis, C. A., Jongejan, J. A., de Vries, S. \& Duine, J. A. (1996). Characterization of gene encoding quinohaemoprotein ethanol dehydrogenase of Comamonas testosteroni. Eur J Biochem 235, 690-698.

Takahashi, J. (1980). Production of intracellular and extracellular protein from $n$-butane by Pseudomonas butanovora sp. nov. Adv Appl Microbiol 26, 117-127.

Takahashi, J., Ichikawa, Y., Sagae, H., Komura, I., Kanou, H. \& Yamada, K. (1980). Isolation and identification of $n$-butaneassimilating bacterium. Agric Biol Chem 44, 1835-1840.

Thomas, P. E., Ryan, D. \& Levin, W. (1976). An improved staining procedure for the detection of the peroxidase activity of cytochrome P-450 on sodium dodecyl sulfate polyacrylamide gels. Anal Biochem 75, 169-176.

Toyama, H., Fujii, A., Matsushita, K., Shinagawa, E., Ameyama, M. \& Adachi, O. (1995). Three distinct quinoprotein alcohol dehydrogenases are expressed when Pseudomonas putida is grown on different alcohols. J Bacteriol 177, 2442-2450.

Van Der Linden, A. C. \& Huybregtse, R. (1969). Occurence of inducible and $\mathrm{NAD}(\mathrm{P})$-independent primary alcohol dehydrogenase in an alkane-oxidizing Pseudomonas. Antonie Leewenboek 35, 344-360.

Van Ginkel, C. G., Welten, H. G. J., Hartmans, S. \& De Bont, J. A. M. (1987). Metabolism of trans-2-butene and butane in Nocardia TB1. J Gen Microbiol 133, 1713-1720.

Van Noorden, C. J. F., Kooij, A., Vogels, I. M. C. \& Frederiks, W. M. (1985). On the nature of the 'nothing dehydrogenase' reaction. Histochem J 17, 1111-1118.

Vestal, J. R. \& Perry, J. J. (1969). Divergent metabolic pathways for propane and propionate utilization by a soil isolate. J Bacteriol 99, 216-221.

Wiegant, W. W. \& de Bont, J. A. M. (1980). A new route for ethylene glycol metabolism in Mycobacterium E44. J Gen Microbiol 120, 325-331.

Woods, N. R. \& Murrell, J. C. (1989). The metabolism of propane in Rhodococcus rhodochrous PNKb1. J Gen Microbiol 135, 2335-2344.

Yamanaka, K. \& Tsuyuki, Y. (1983). A new dye-linked alcohol dehydrogenase (vanillyl alcohol dehydrogenase) from Rhodopseudomonas acidophila M402: purification, identification of reaction product and substrate specificity. Agric Biol Chem 47, 2173-2183. 
Yuste, L., Canosa, I. \& Fernando, R. (1998). Carbon-sourcedependent expression of the PalkB promoter from the Pseudomonas oleovorans alkane degradation pathway. J Bacteriol 180, 5218-5226.

Zarnt, G., Schrader, T. \& Andreesen, J. R. (1997). Degradation of tetrahydrofurfuryl alcohol by Ralstonia eutropha is initiated by an inducible pyrroloquinoline quinone-dependent alcohol dehydrogenase. Appl Environ Microbiol 63, 4891-4898.
Zheng, Y. \& Bruice, T. (1997). Conformation of coenzyme pyrroloquinoline quinone and role of $\mathrm{Ca}^{2+}$ in the catalytic mechanism of quinoprotein methanol dehydrogenase. Proc Natl Acad Sci US A 94, 11881-11886.

Received 22 August 2000; revised 6 November 2000; accepted 13 November 2000. 